\title{
Oxidative Modification of Tryptophan-Containing Peptides
}

Petersen, Jonas; Christensen, Pia Katrine; Nielsen, Mathias T; Mortensen, Kim T.; Komnatnyy, Vitaly V.; Nielsen, Thomas E.; Qvortrup, Katrine

Published in:

A C S Combinatorial Science

Link to article, DOI:

10.1021/acscombsci.8b00014

Publication date:

2018

Document Version

Peer reviewed version

Link back to DTU Orbit

Citation (APA):

Petersen, J., Christensen, P. K., Nielsen, M. T., Mortensen, K. T., Komnatnyy, V. V., Nielsen, T. E., \& Qvortrup, K. (2018). Oxidative Modification of Tryptophan-Containing Peptides. A C S Combinatorial Science, 20(6). https://doi.org/10.1021/acscombsci.8b00014

\section{General rights}

Copyright and moral rights for the publications made accessible in the public portal are retained by the authors and/or other copyright owners and it is a condition of accessing publications that users recognise and abide by the legal requirements associated with these rights.

- Users may download and print one copy of any publication from the public portal for the purpose of private study or research.

- You may not further distribute the material or use it for any profit-making activity or commercial gain

- You may freely distribute the URL identifying the publication in the public portal

If you believe that this document breaches copyright please contact us providing details, and we will remove access to the work immediately and investigate your claim 


\title{
Oxidative Modification of Tryptophan-Containing Peptides
}

\author{
2 Jonas Petersen, ${ }^{\dagger}$ Katrine E. Christensen, ${ }^{\dagger}$ Mathias T. Nielsen, ${ }^{\dagger}$ Kim T. Mortensen, ${ }^{\dagger}$ Vitaly V. Komnatnyy, ${ }^{\dagger}$ \\ ${ }_{3}$ Thomas E. Nielsen, ${ }^{\dagger,}, \S$ and Katrine Qvortrup ${ }^{*}+\infty$ \\ $4{ }^{\dagger}$ Department of Chemistry, Technical University of Denmark, DK-2800 Kongens Lyngby, Denmark \\ $5{ }^{*}$ Department of Immunology and Microbiology, University of Copenhagen, DK-2200 Copenhagen, Denmark \\ ${ }_{6}^{8}$ Singapore Centre for Environmental Life Sciences Engineering, Nanyang Technological University, Singapore 637551 \\ 7 S Supporting Information
}

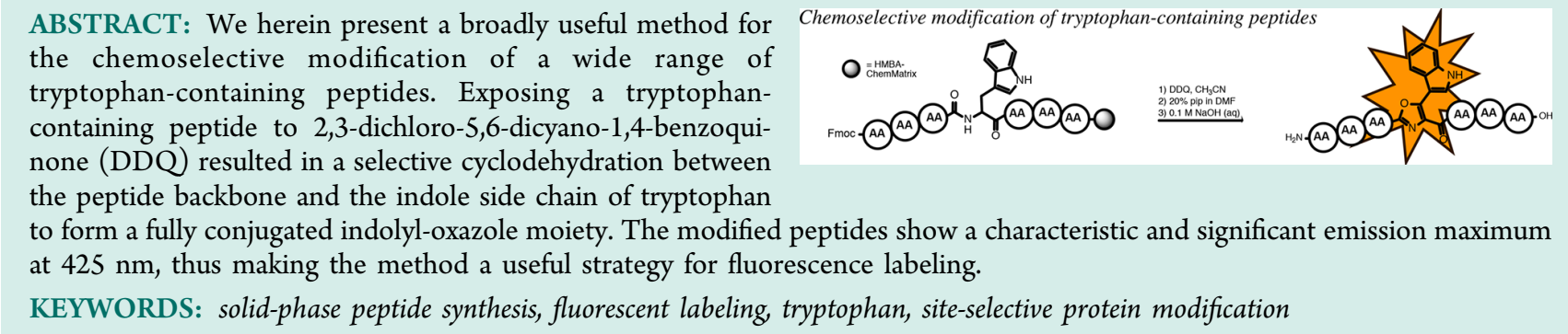

\section{INTRODUCTION}

18 Fluorescence labeling of proteins and peptides is fundamental 19 for the study of biological systems, as it can provide detailed 20 visualization of complex cellular processes. ${ }^{1}$ The visualization of 21 biological processes has been crucial for our understanding of 22 molecular dynamics and the development of new potent drugs. 23 Nowadays, the most common approach to fluorescence 24 labeling of proteins comprises the introduction of fluorescent 25 small molecules to the nucleophilic side chain of lysine, serine, 26 threonine, or cysteine residues in a peptide or protein of 27 interest. $^{2}$ However, such strategies often suffer from poor site 28 selectivity, where multiple residues are modified. Though less 29 established, chemoselective functionalization of other residues, 30 such as methionine, ${ }^{3}$ glutamine, ${ }^{4}$ arginine, ${ }^{5} \mathrm{~N}$-terminal serine/ 31 threonine, ${ }^{6}$ tyrosine, ${ }^{7}$ and tryptophan, ${ }^{8}$ has been described. 32 Among these residues, tryptophan is particularly interesting 33 because of its scarce abundance in proteins. With a natural 34 abundance of only $1.09 \%,{ }^{9}$ many proteins of interest will 35 contain only a single or few tryptophan residues accessible for 36 functionalization, thus enabling high control of the position for 37 modification. Furthermore, the relative large size of organic 38 dyes, including undesired physiochemical properties may give 39 rise to several challenges, that compromise the biologically 40 activity of the labeled target. Therefore, labeling strategies that 41 introduce minimal structural perturbation to the peptide of 42 interest is of high importance.

43 Herein, we describe our efforts toward the oxidative 44 modification of small peptides containing tryptophan. The 45 conjugated nature of the generated indolyl-oxazole moiety 46 emits blue-fluorescence, ${ }^{10}$ which may advantageously be 47 utilized for spectroscopic studies of biological systems. For 48 instance, the indolyl-oxazole moiety of diazonamide A 49 derivatives has been utilized as intrinsic fluorophores for in 50 vitro cellular uptake studies. ${ }^{11}$ In addition, the indolyl-oxazole scaffold is present in a variety of naturally occurring biologically 51 active compounds including those shown in Figure $1,{ }^{12-15}$ as $52 \mathrm{f1}$ well as cyclic derivatives such as the diazonamides. ${ }^{11}$

\section{RESULTS AND DISCUSSION}

54

Using standard reagents for solid-phase peptide synthesis, the 55 HMBA linker was easily immobilized and synthetically 56 elaborated on an amino-functionalized ChemMatrix resin 57 (Table 1). Initially, a range of conditions for the oxidative $58 \mathrm{tl}$ cyclodehydration of model compound 6 (Scheme 1) was $59 \mathrm{~s} 1$ examined. ${ }^{16}$ Oxidation of the $\alpha$-carbon of indoles has been 60 performed with the dehydrogenating agent DDQ to form the 61 keto-indole derivative. ${ }^{16}$ Therefore, it was expected that DDQ 62 could be a suitable reagent for the oxidative cyclodehydration of 63 tryptophan. Furthermore, cyclodehydration of keto-indoles has 64 been carried out with a mixture of triphenylphosphine, metallic 65 iodine, and triethylamine in $\mathrm{CH}_{2} \mathrm{Cl}_{2}$, to form a conjugated 66 indolyl-oxazole moiety. ${ }^{17}$ Various solvents were screened 67 (entries A-G), and it was disclosed that exposure of a 68 tryptophan-containing oligopeptide to DDQ (4 equiv) in 69 $\mathrm{MeCN}$ led to near-quantitative conversion into the desired 70 indolyl-oxazole product 9 (Scheme 1). Interestingly, the 71 peptide was fully converted to the desired indolyl-oxazole 72 derivative with only two equivalents of DDQ (entry J). The 73 reaction most likely occurs via the $\alpha, \beta$-unsaturated imine 774 (Scheme 1). However, in reactions where partial formation of 75 the ketone product $\mathbf{8}$ was initially observed, it was noted that 76 prolonged reaction times resulted in full conversion to the 77 desired cyclo-dehydrated product 9.

Received: January 30, 2018

Revised: April 13, 2018

Published: May 2, 2018 


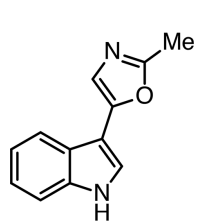

1: Primprinine 2: Labradorin $1(\mathrm{R}=\mathrm{iPr})$ 3: Labradorin $2(\mathrm{R}=n \mathrm{Bu})$

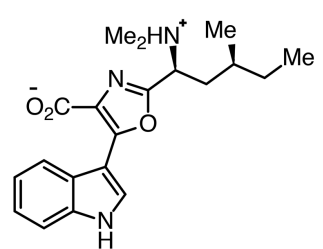

4: Martefragin A

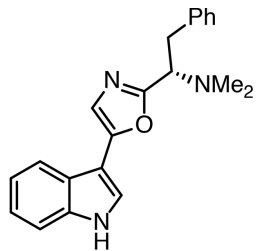

5: Almazole C

Figure 1. Biologically active indolyl-oxazole natural products.

Table 1. Chemical Data for the Indolyl-oxazoles $10 \mathrm{~A}-\mathrm{AQ}$
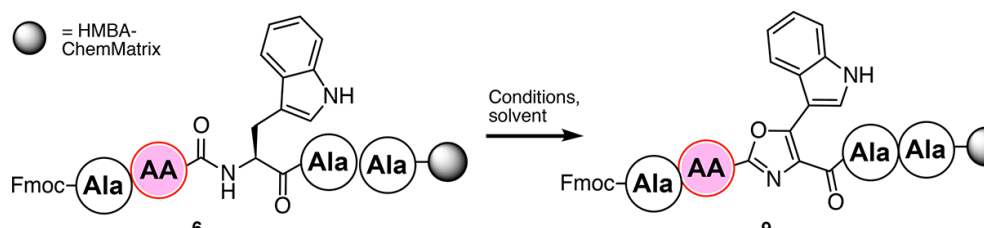

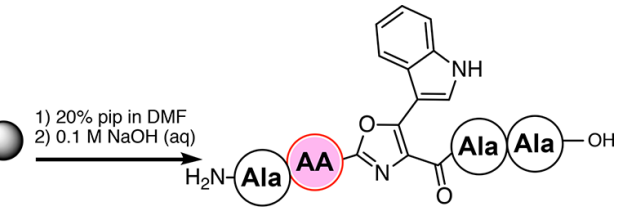

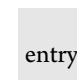

conditions$$
\text { A }
$$

$$
\text { (1) }
$$

$$
\text { (1) }
$$

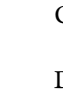

$$
\text { (1) }
$$

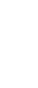$$
\text { (1) }
$$
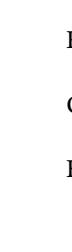

(n)

$$
\text { ; }
$$
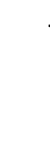

$$
\text { in }
$$

$$
\text { s. }
$$

$$
\text { (n) }
$$
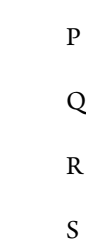$$
\text { (n) }
$$

$$
3
$$
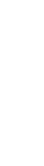

\footnotetext{
$\begin{array}{cccccc}\mathrm{V} & \text { Asp } & \mathrm{DDQ}(2 \text { equiv) } & \mathrm{CH}_{3} \mathrm{CN} & 45 & 15 \\ { }^{a} \text { Crude purities. } & { }^{b} \text { All compounds were purified by } & \text { prepHPLC beforc }\end{array}$
}

79 The sequence tolerance of the site-selective tryptophan 80 oxidation protocol was investigated through the synthesis of a combinatorial library of natural amino acids and common 81 protective groups (entry L-AO). Gratifyingly, the developed 82 
Scheme 1. Synthesis of Indolyl-oxazole-Functionalized Peptide 9

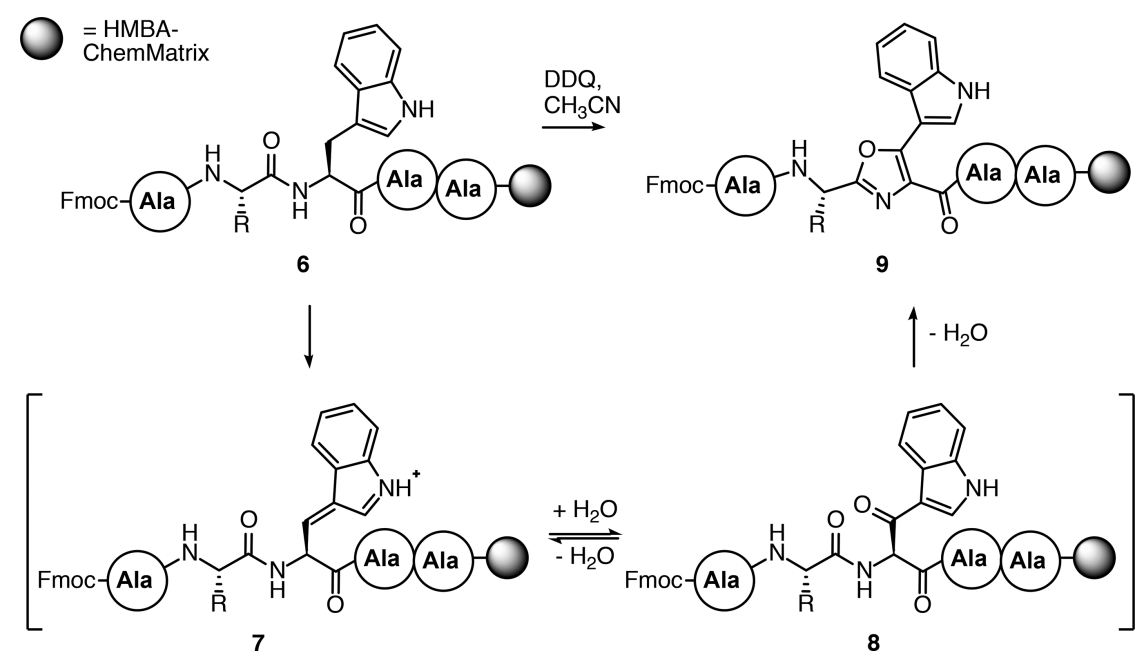

Scheme 2. Synthesis of Peptides 11(J,L-AO)
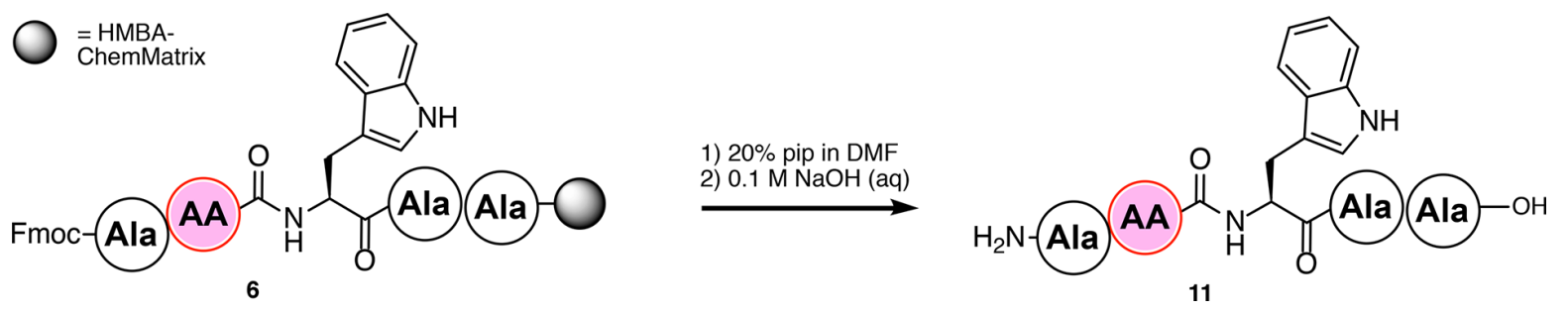

83 protocol showed compatibility with a wide range of peptides 84 and generally only the desired product was observed by UP85 LCMS (see Supporting Information). Unfortunately, non86 protected lysine residues were not tolerated (entry AG). Here a 87 range of byproducts was observed by UPLC, including a 88 nucleophilic addition of the lysine side-chain amino group to 89 the conjugated imine (7) as well as a Michael reaction between 90 the amino group and DDQ.

91 The isolated yields of indolyl oxazole peptides are in the 92 range typically observed for solid-phase synthesis followed by 93 preparative HPLC purification. From our results, we cannot 94 identify a correlation between purity and isolated yields neither 95 is there apparent structure-yield correlation.

96 Furthermore, the methodology was investigated for peptides 97 containing more than one tryptophan residue (entry AP-AQ). 98 Using two and three equivalents of $\mathrm{DDQ}$ respectively, peptides 99 containing two or three indolyl-oxazole moieties were obtained 100 (see Supporting Information).

101 In order to investigate the potential of the technique for 102 fluorescent labeling, the fluorescence properties of the indolyl103 oxazole containing peptide 10(J,L-AO) was measured and 104 compared to the emission spectrum of the corresponding 105 nonoxidized peptides 11(J,L-AO), Scheme 2. 106 As shown in Figure 2, the indolyl-oxazole containing peptides 107 show a remarkably change in fluorescence with a distinct band 108 now appearing at $425 \mathrm{~nm}$. Importantly, this absorption is not 109 affected by the presence of aromatic side chain functionalities in 110 naturally occurring amino acids.

111 Having identified conditions allowing for oxidative cyclo112 dehydration of tryptophan in various peptides, we sought to 113 demonstrate the use of this methodology in the labeling of 114 biological relevant peptides. GLP-1 is a 30 amino acid-

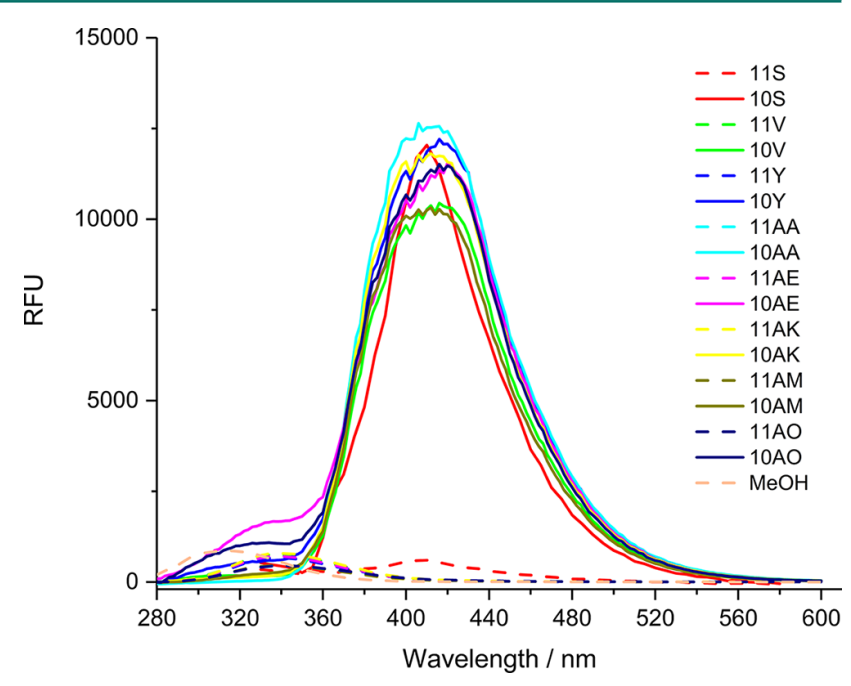

Figure 2. Fluorescence measurement of compound 10J,L-AO and $11 \mathrm{~J}, \mathrm{~L}-\mathrm{AO}$.

containing peptide hormone that possesses several pharmaco- 115 logical properties, making it a subject of intensive investigation. 116 Gratifyingly, when exposing GLP-1(12), to the DDQ 117 conditions the desired fluorescence labeled indolyl-oxazole 118 analog 13 was formed (Figure 2) with a satisfactory conversion 119 of $85 \%$, as confirmed by HPLC.

Currently, the methodology has only been demonstrated for 121 immobilized peptides that tolerate acetonitrile. It would be 122 desirable to adapt this chemistry to aqueous conditions, thereby 123 allowing indolyl-oxazole formation in proteins. This would 124 
GLP-1 (12)
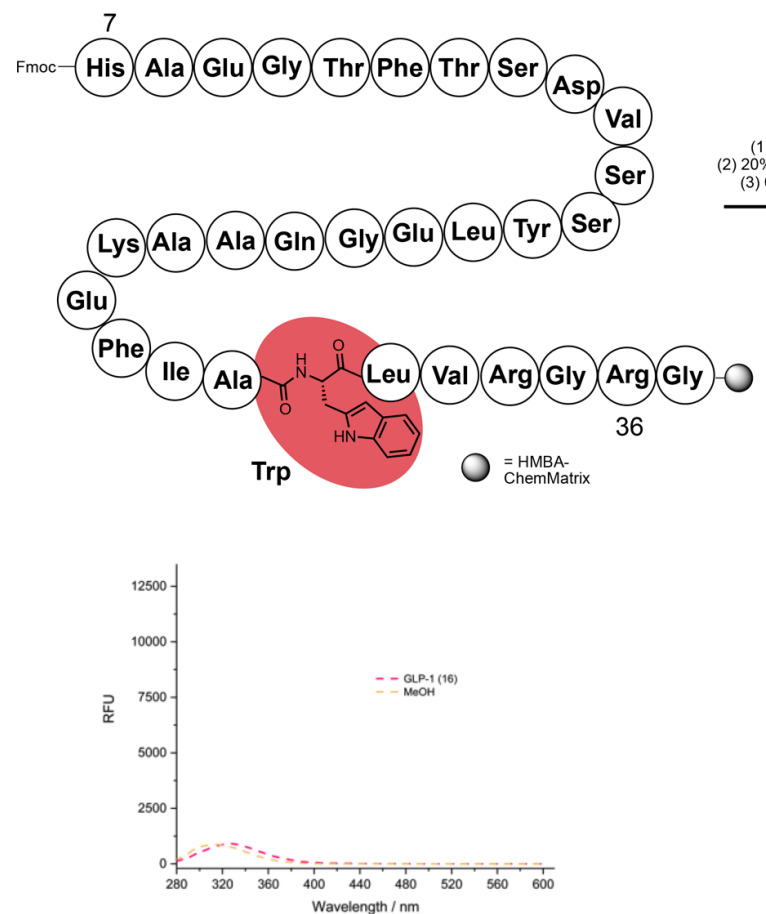

Fluorescent labeled GLP-1 (13)
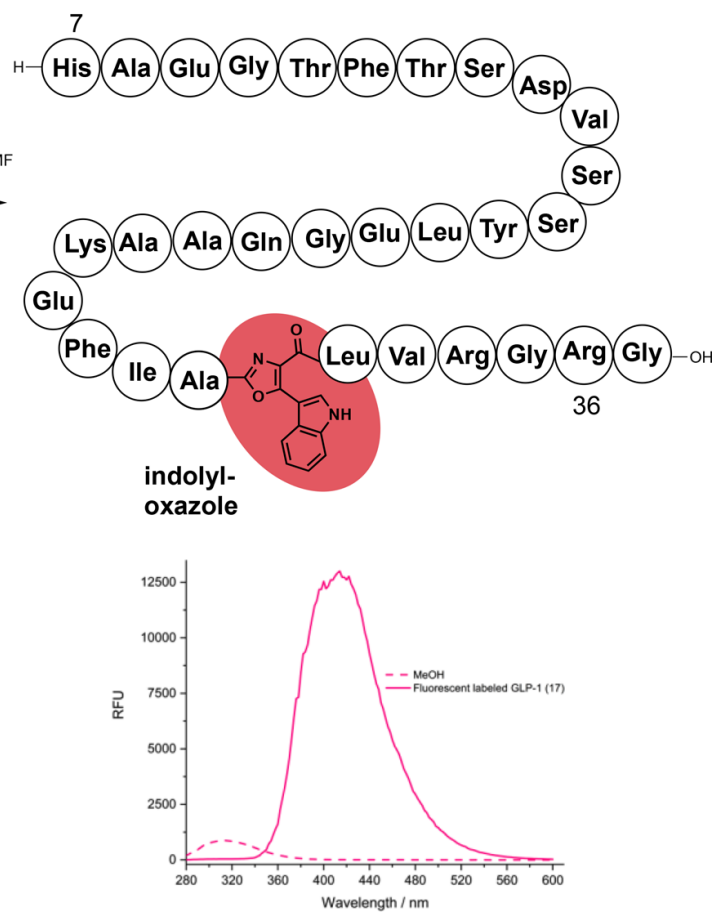

Figure 3. Fluorescent labeling of GLP-1.

125 require the development of a more stable dehydrogenation 126 reagent, which resists hydrolysis in aqueous solutions.

\section{$127 \square$ CONCLUSIONS}

128 In summary, we report a method that allows for the 129 chemoselective labeling of tryptophan-containing peptide 130 residues. DDQ-mediated oxidative cyclization leads to the 131 installation of an indolyl-oxazole moiety with unique 132 fluorescence properties. We further demonstrate that the 133 indolyl-oxazole moiety selectively may be installed in a 134 pharmaceutically relevant peptide, thereby emphasizing the 135 important potential of the methodology to illuminate biological 136 mechanism of relevance to drug discovery.

\section{EXPERIMENTAL SECTION}

138 General Methods. All reagents and materials used were 139 purchased from ordinary chemical suppliers and were used 140 without purification. The solvents used were of standard HPLC 141 grade. Solid-phase synthesis was carried out using plastic142 syringe techniques. Flat-bottomed PE-syringes were fitted with 143 PP-filters and situated in Teflon valves equipped with Teflon 144 tubing allowing for a moderate vacuum to be applied to the 145 syringes.

146 Yields of solid-phase synthesis protocols are corrected for salt 147 contents and given as percentage of product mass recovery to 148 the theoretical product loading mass, calculated from the resin 149 loading $(4 \mathrm{mmol} / \mathrm{g})$ as specified by the supplier.

150 Products were analyzed on a Waters Alliance reverse-phase 151 HPLC system consisting of a Waters 2695 Separations Module 152 equipped with a Symmetry C18 column $(3.5 \mu \mathrm{m}, 4.6 \times 75 \mathrm{~mm}$, 153 column temp $25{ }^{\circ} \mathrm{C}$, flow rate $1 \mathrm{~mL} / \mathrm{min}$ ) and a Waters 154 Photodiode Array Detector (detecting at $215 \mathrm{~nm}$ ). Elution was 155 carried out in a linear reversed phase gradient fashion (gradient 156 A: $0 \%$ organic for $0.2 \mathrm{~min}, 0 \%$ organic to $100 \%$ organic in 10 min, hold for $1 \mathrm{~min}, 100 \%$ organic to $0 \%$ organic in $0.3 \mathrm{~min}, 157$ hold for $1.5 \mathrm{~min}$, gradient B: $0 \%$ organic for $0.2 \mathrm{~min}, 0 \% 158$ organic to $40 \%$ organic in $10 \mathrm{~min}, 40 \%$ organic to $100 \%$ organic 159 in $0.8 \mathrm{~min}$, hold for $1 \mathrm{~min}, 100 \%$ organic to $0 \%$ organic in 0.3160 min, hold for $1.5 \mathrm{~min}$ ) combining water and acetonitrile 161 (buffered with $0.1 \%$ (v/v) TFA).

Preparative RP-HPLC was carried out on a Waters Alliance 163 reverse-phase HPLC system consisting of a Waters 2545 Binary 164 Gradient Module equipped with an xBridge TM.

165

Prep BEH130 C18 column OBDTM $(5 \mu \mathrm{m}, 19 \times 100 \mathrm{~mm}, 166$ column temp $25{ }^{\circ} \mathrm{C}$, flow rate $20 \mathrm{~mL} / \mathrm{min}$ ), a Waters 167 Photodiode Array Detector (detecting at 210-600 nm), a 168 Waters UV Fraction Manager and a Waters 2767 Sample 169 Manager. Elution was carried out in a linear reversed phase 170 gradient fashion combining water and acetonitrile (buffered 171 with $0.2 \%(\mathrm{v} / \mathrm{v})$ TFA).

172

1D and 2D NMR spectra were recorded using a Varian Unity 173 Inova-500 MHz, a Varian Mercury-300 MHz instrument, a 174 Bruker Ascend- $400 \mathrm{MHz}$ instrument equipped with a $5 \mathrm{~mm} 175$ Prodigy cryoprobe or a Bruker Avance- $800 \mathrm{MHz}$ instrument, 176 equipped with a $5 \mathrm{~mm}$ cryoprobe TCI, in DMSO- $d_{6}$ or $\mathrm{CDCl}_{3} 177$ using the residual DMSO or $\mathrm{CHCl}_{3}$ solvent peaks, respectively, 178 as the internal standard. All ${ }^{13} \mathrm{C}$ NMR spectra were proton 179 decoupled. DQF-COSY, HSQC, HMBC, and 2D NOESY 180 spectra were acquired using standard pulse sequences. 181

LC-DAD-HRMS was performed on an Agilent 1100 LC 182 system equipped with a Agilent Technologies Diode Array 183 Detector and a Luna C18 column $(3 \mu \mathrm{m}, 50 \mathrm{~mm} \times 2 \mathrm{~mm}, 184$ column temp $40{ }^{\circ} \mathrm{C}$, flow rate $\left.400 \mu \mathrm{L} / \mathrm{min}\right)$. Separation was 185 achieved using a linear reversed phase gradient (20\% to $100 \% 186$ organic in $8 \mathrm{~min}$, hold for $2 \mathrm{~min}, 100 \%$ to $20 \%$ organic in $1 \mathrm{~min}, 187$ hold for $4 \mathrm{~min}$ ) again combining water and acetonitrile 188 (buffered with $20 \mathrm{mM} \mathrm{HCO} \mathrm{HCO}_{2} \mathrm{H}$ ). The LC was coupled to a 189 Micromass LCT orthogonal time-of-flight mass spectrometer, 190 
191 equipped with Lock Mass probe and operated in positive 192 electrospray mode.

193 General Solid-Phase Procedures. The commercial 194 available amino functionalized ChemMatrix $(0.4 \mathrm{mmol} / \mathrm{g})$ 195 was washed with DMF. Coupling of the first amino acid 196 building block to the resin was carried out as follows. Dry resin 197 was weighed in a syringe, equipped with a PP-filter. The amino 198 acid (3 equiv) was weighed, dissolved in DMF $(0.02 \mathrm{~mL} / \mathrm{mg}$ 199 resin) and $N$-ethylmorpholine (4 equiv) was added using a 200 microliter pipet. $N$-[(1H-Benzotriazol-1-yl)(dimethylamino)201 methylene]-N-methylmethanaminium tetrafluoroborate $\mathrm{N}$ 202 oxide (TBTU, 2.9 equiv) was weighed and likewise added. 203 The solution was transferred to the resin, the swelled resin 204 stirred gently with a spatula and allowed to react for $2 \mathrm{~h}$. The 205 resin was filtered, washed with DMF $(\times 6)$ and $\mathrm{CH}_{2} \mathrm{Cl}_{2}(\times 6)$ 206 and lyophilized. The Fmoc-group was removed by swelling the 207 resin in a solution of piperidine $(20 \% \mathrm{v} / \mathrm{v})$ in DMF for $2 \mathrm{~min}$, 208 filtering and then swelling the resin again in a fresh solution of 209 piperidine $(20 \% \mathrm{v} / \mathrm{v})$ in DMF for $18 \mathrm{~min}$. The resin was 210 washed with DMF $(\times 6)$ and $\mathrm{CH}_{2} \mathrm{Cl}_{2}(\times 6)$ and lyophilized.

211 The oxidatively modified peptides were liberated from the 212 HMBA-functionalized ChemMatrix resin by addition of $4 \mathrm{~mL}$ 213 of $0.1 \mathrm{~N}$ aqueous $\mathrm{NaOH}$. The syringes were left overnight 214 under vigorous shaking followed by neutralization with $0.1 \mathrm{~N}$ $215 \mathrm{HCl}(\mathrm{aq})$. The aqueous solutions containing the peptides were 216 collected by filtration and the resins were washed with water $217(\times 5)$ and $\mathrm{MeCN}(\times 5)$. The purity of the crude reaction 218 mixture was monitored by UPLC-MS. The MeCN and water 219 was removed by evaporation and freeze-drying. The residue was 220 redissolved in $3 \mathrm{~mL}$ of DMF, filtrated and purified by 221 preparative RP-HPLC. The solvent was removed from the 222 product-containing fractions by evaporation and freeze-drying 223 before NMR data collection and measurement of the 224 fluorescence properties using a Tecan microplate reader.

225 Evaluation of Spectroscopic Properties. The fluores226 cence experiments were conducted by soluting each of the 227 peptides in methanol. The fluorescence of the peptides was 228 monitored using a Tecan microplate reader, which first records 229 the absorbance properties to identify the required wavelength 230 for excitation of the compound. The fluorescence was then 231 measured in the arbitrary unit 'Relative Fluorescence Units' 232 (RFU) and plotted against their respective wavelengths. The 233 measurements were acquired setting the gain to 70 .

\section{$234 \square$ ASSOCIATED CONTENT}

\section{S Supporting Information}

236 The Supporting Information is available free of charge on the 237 ACS Publications website at DOI: 10.1021/acscombs238 ci. 8 b00014.

Analytical data $\left({ }^{1} \mathrm{H}\right.$ and ${ }^{13} \mathrm{C}$ NMR spectra and LC-MS

240 chromatograms) of all compounds synthesized (PDF)

\section{$241 \square$ AUTHOR INFORMATION}

\section{Corresponding Author}

243 *E-mail: kaqvo@kemi.dtu.dk.

\section{ORCID 1}

245 Katrine Qvortrup: 0000-0003-3828-2069

246 Notes

247 The authors declare no competing financial interest.

\section{ACKNOWLEDGMENTS}

We thank the Carlsberg Foundation, and the Technical 249 University of Denmark for financial support.

\section{REFERENCES}

(1) (a) Jonassen, I.; Havelund, S.; Hoeg-Jensen, T.; Steensgaard, D. 252 B.; Wahlund, P. O.; Ribel, U. Design of the Novel Protraction 253 Mechanism of Insulin Degludec, an Ultra-long-Acting Basal Insulin. 254 Pharm. Res. 2012, 29, 2104-2114. (b) Löwik, D. W.; Leunissen, E. H.; 255 van den Heuvel, M.; Hansen, M. B.; van Hest, J. C. Stimulus 256 responsive peptide based materials. Chem. Soc. Rev. 2010, 39, 3394- 257 3412. (c) Yim, C. B.; Dijkgraaf, I.; Merkx, R.; Versluis, C.; Eek, A.; 258 Mulder, G. E.; Rijkers, D. T.; Boerman, O. C.; Liskamp, R. M. 259 Synthesis of DOTA-Conjugated Multimeric $\left[\mathrm{Tyr}^{3}\right]$ Octreotide Pep- 260 tides via a Combination of $\mathrm{Cu}(\mathrm{I})$-Catalyzed "Click" Cycloaddition and 261 Thio Acid/Sulfonyl Azide "Sulfo-Click" Amidation and Their in Vivo 262 Evaluation. J. Med. Chem. 2010, 53, 3944-3953.

(2) (a) Takaoka, Y.; Ojida, A.; Hamachi, I. Protein organic chemistry 264 and applications for labeling and engineering in live-cell systems. 265 Angew. Chem., Int. Ed. 2013, 52, 4088-4106; Angew. Chem. 2013, 125, 266 4182-4200. (b) Schoffelen, S.; van Eldijk, M. B.; Rooijakkers, B.; 267 Raijmakers, R.; Heck, A. J. R.; van Hest, J. C. M. Metal-free and pH- 268 controlled introduction of azides in proteins. Chem. Sci. 2011, 2, 701- 269 705.

(3) (a) Carlsson, F. H. The selective S-alkylation of a methionine 271 residue in an elapid venom cardiotoxin. Int. J. Biochem. 1987, 19, 915- 272 921. (b) Kramer, J. R; Deming, T. J. Reversible chemoselective 273 tagging and functionalization of methionine containing peptides. 274 Chem. Commun. 2013, 49, 5144-5146.

(4) Fontana, A.; Spolaore, B.; Mero, A.; Veronese, F. M. Site-specific 276 modification and PEGylation of pharmaceutical proteins mediated by 277 transglutaminase. Adv. Drug Delivery Rev. 2008, 60, 13-28.

(5) Gauthier, M. A.; Klok, H. A. Arginine-Specific Modification of 279 Proteins with Polyethylene Glycol. Biomacromolecules 2011, 12, 482- 280 493.

281

(6) (a) Geoghegan, K. F.; Stroh, J. G. Site-directed conjugation of 282 nonpeptide groups to peptides and proteins via periodate oxidation of 283 a 2-amino alcohol. Application to modification at N-terminal serine. 284 Bioconjugate Chem. 1992, 3, 138-146. (b) Ning, X.; Temming, R. P.; 285 Dommerholt, J.; Guo, J.; Ania, D. B.; Debets, M. F.; Wolfert, M. A.; 286 Boons, G. J.; van Delft, F. L. Protein Modification by Strain-Promoted 287 Alkyne-Nitrone Cycloaddition. Angew. Chem., Int. Ed. 2010, 49, 288 3065-3068; Angew. Chem. 2010, 122, 3129-3132.

(7) (a) Ban, H.; Gavrilyuk, J.; Barbas, C. F., III Tyrosine 290 Bioconjugation through Aqueous Ene-Type Reactions: A Click-Like 291 Reaction for Tyrosine. J. Am. Chem. Soc. 2010, 132, 1523-1525. 292 (b) Ban, H.; Nagano, M.; Gavrilyuk, J.; Hakamata, W.; Inokuma, T.; 293 Barbas, C. F., III Facile and Stabile Linkages through Tyrosine: 294 Bioconjugation Strategies with the Tyrosine-Click Reaction. Bio- 295 conjugate Chem. 2013, 24, 520-532. (c) Jones, M. W.; Mantovani, G.; 296 Blindauer, C. A.; Ryan, S. M.; Wang, X.; Brayden, D. J.; Haddleton, D. 297 M. Direct Peptide Bioconjugation/PEGylation at Tyrosine with Linear 298 and Branched Polymeric Diazonium Salts. J. Am. Chem. Soc. 2012, 134, 299 7406-7413. (d) Tilley, S. D.; Francis, M. B. Tyrosine-Selective 300 Protein Alkylation Using $\pi$-Allylpalladium Complexes. J. Am. Chem. 301 Soc. 2006, 128, 1080-1081.

(8) (a) Antos, J. M.; Francis, M. B. Selective Tryptophan 303 Modification with Rhodium Carbenoids in Aqueous Solution. J. Am. 304 Chem. Soc. 2004, 126, 10256-10257. (b) Antos, J. M.; McFarland, J. 305 M.; Iavarone, A. T.; Francis, M. B. Chemoselective Tryptophan 306 Labeling with Rhodium Carbenoids at Mild pH. J. Am. Chem. Soc. 307 2009, 131, 6301-6308. (c) Ruiz-Rodríguez, J.; Albericio, F.; Lavilla, R. 308 Postsynthetic Modification of Peptides: Chemoselective C-Arylation 309 of Tryptophan Residues. Chem. - Eur. J. 2010, 16, 1124-1127. 310 (d) Williams, T. J.; Reay, A. J.; Whitwood, A. C.; Fairlamb, I. J. A mild 311 and selective Pd-mediated methodology for the synthesis of highly 312 fluorescent 2-arylated tryptophans and tryptophan-containing pep- 313 tides: a catalytic role for $\mathrm{Pd}^{0}$ nanoparticles? Chem. Commun. 2014, 50, 314 
315 3052-3054. (e) Siti, W.; Khan, A. K.; de Hoog, H. P.; Liedberg, B.; 316 Nallani, M. Photo-induced conjugation of tetrazoles to modified and 317 native proteins. Org. Biomol. Chem. 2015, 13, 3202-3206. (f) Perekalin, 318 D. S.; Novikov, V. V.; Pavlov, A. A.; Ivanov, I. A.; Anisimova, N. Y.; 319 Kopylov, A. N.; Volkov, D. S.; Seregina, I. F.; Bolshov, M. A.; Kudinov, 320 A. R. Selective Ruthenium Labeling of the Tryptophan Residue in the 321 Bee Venom Peptide Melittin. Chem. - Eur. J. 2015, 21, 4923-4925. 322 (g) Chen, Z.; Popp, B. V.; Bovet, C. L.; Ball, Z. T. Site-Specific Protein 323 Modification with a Dirhodium Metallopeptide Catalyst. ACS Chem. 324 Biol. 2011, 6, 920-925. (h) Mendive-Tapia, L.; Preciado, S.; Garcia, J.; 325 Ramon, R.; Kielland, N.; Albericio, F.; Lavilla, R. New peptide 326 architectures through $\mathrm{C}-\mathrm{H}$ activation stapling between tryptophan327 phenylalanine/tyrosine residues. Nat. Commun. 2015, 6, 7160. 328 (i) Hansen, M. B.; Hubálek, F.; Skrydstrup, T.; Hoeg-Jensen, T. 329 Chemo- and Regioselective Ethynylation of Tryptophan-Containing 330 Peptides and Proteins. Chem. - Eur. J. 2016, 22, 1572-1576.

331 (9) UniProtKB/Swiss-Prot protein knowledgebase release 201508 332 statistics. http://web.expasy.org/docs/relnotes/relstat.html.

333 (10) Grotkopp, O.; Ahmad, A.; Frank, W.; Müller, T. J. J. Blue334 luminescent 5-(3-indolyl)oxazoles via microwave-assisted three335 component coupling-cycloisomerization-Fischer indole synthesis. 336 Org. Biomol. Chem. 2011, 9, 8130-8140.

337 (11) Hong, J. Natural Product Synthesis at the Interface of Chemistry 338 and Biology. Chem. - Eur. J. 2014, 20, 10204-10212.

339 (12) Naik, S. R.; Harindran, J.; Varde, A. B. Pimprinine, an 340 extracellular alkaloid produced by StreptomycesCDRIL-312: fermen341 tation, isolation and pharmacological activity. J. Biotechnol. 2001, 88, $3421-10$.

343 (13) Takahashi, S.; Matsunaga, T.; Hasegawa, C.; Saito, H.; Fujita, 344 D.; Kiuchi, F.; Tsuda, Y. Martefragin A, a Novel Indole alkaloid 345 Isolated from Red Alga, Inhibits Lipid Peroxidation. Chem. Pharm. 346 Bull. 1998, 46, 1527-1529.

347 (14) Pettit, G. R.; Knight, J. C.; Herald, D. L.; Davenport, R.; Pettit, 348 R. K.; Tucker, B. E.; Schmidt, J. M. Isolation of Labradorins 1 and 2 349 from Pseudomonas syringae pv. coronafaciens. J. Nat. Prod. 2002, 65, $3501793-1797$.

351 (15) Fresneda, P. M.; Castañeda, M.; Blug, M.; Molina, P. 352 Iminophosphorane-based preparation of 2,5-disubstituted oxazole 353 derivatives: synthesis of the marine alkaloid almazole C. Synlett 354 2007, 38, 324-326.

355 (16) Oikawa, Y.; Yonemitsu, O. Selective oxidation of the side chain 356 at C-3 of indoles. J. Org. Chem. 1977, 42, 1213-1216.

357 (17) Roy, S.; Haque, S.; Gribble, G. W. Synthesis of Novel Oxazolyl358 indoles. Synthesis 2006, 23, 3948-3954. 